IZA DP No. 5080

Why Does Intermarriage Increase Immigrant Employment? The Role of Networks

Delia Furtado

Nikolaos Theodoropoulos

July 2010 


\title{
Why Does Intermarriage Increase Immigrant Employment? The Role of Networks
}

\author{
Delia Furtado \\ University of Connecticut \\ and IZA \\ Nikolaos Theodoropoulos \\ University of Cyprus \\ and CReAM \\ Discussion Paper No. 5080 \\ July 2010 \\ IZA \\ P.O. Box 7240 \\ 53072 Bonn \\ Germany \\ Phone: +49-228-3894-0 \\ Fax: +49-228-3894-180 \\ E-mail: iza@iza.org
}

Any opinions expressed here are those of the author(s) and not those of IZA. Research published in this series may include views on policy, but the institute itself takes no institutional policy positions.

The Institute for the Study of Labor (IZA) in Bonn is a local and virtual international research center and a place of communication between science, politics and business. IZA is an independent nonprofit organization supported by Deutsche Post Foundation. The center is associated with the University of Bonn and offers a stimulating research environment through its international network, workshops and conferences, data service, project support, research visits and doctoral program. IZA engages in (i) original and internationally competitive research in all fields of labor economics, (ii) development of policy concepts, and (iii) dissemination of research results and concepts to the interested public.

IZA Discussion Papers often represent preliminary work and are circulated to encourage discussion. Citation of such a paper should account for its provisional character. A revised version may be available directly from the author. 


\section{ABSTRACT \\ Why Does Intermarriage Increase Immigrant Employment? The Role of Networks}

Social networks are commonly understood to play a large role in the labor market success of immigrants. Using 2000 U.S. Census data, this paper examines whether access to native networks, as measured by marriage to a native, increases the probability of immigrant employment. We start by confirming in both least squares and instrumental variables frameworks that marriage to a native indeed increases immigrant employment rates. Next, we show that the returns to marrying a native are not likely to arise solely from legal status acquired through marriage or characteristics of native spouses. We then present several pieces of evidence suggesting that networks obtained through marriage play an important part in explaining the relationship between marriage decisions and employment.

JEL Classification: J61, J12, J21

Keywords: immigration, marriage, employment, networks

Corresponding author:

Delia Furtado

Department of Economics

University of Connecticut

341 Mansfield Road

Unit 1063

Storrs, CT 06269-1063

USA

E-mail: Delia.Furtado@uconn.edu

\footnotetext{
* We are grateful to Kristin Butcher, Yannis Ioannides, and especially Stephen Ross for extremely helpful comments. We would also like to thank Thomas Bauer, Michael Ben-Gad, Sarah Brown, Aimee Chin, Albrecht Glitz, Jungho Kim, Pia Orrenius and Kostas Tatsiramos as well as seminar and conference participants at Clark University, Tulane University, Wellesley College, the University of Connecticut, the SOLE (2009), RES (2009), WPEG (2009), and SEA (2008) Meetings, the European Workshop on Labour Markets and Demographic Change (2009), the Local Dynamics and Immigrant Economic Outcomes International Workshop (2008), and CSWEP's CeMent National Workshop (2010). A previous version of this paper was circulated under the title, "Intermarriage and Immigrant Employment: The Role of Networks."
} 


\section{Introduction}

It is often said that when it comes to labor market success, what matters is not what you know but who you know. Norms enforced within social networks might influence people's work ethic and job search intensities. Perhaps more importantly, networks play a direct role in matching workers with jobs. Given that immigrants are less likely to be familiar with formal job search methods and less qualified for the high skill jobs that tend to use them, networks may be especially valuable for the labor market success of the foreign born. In this paper, we use the relationship between immigrant marriage patterns and employment rates to gain insight into the role of networks in immigrant assimilation. We first replicate the finding in the literature that marriage to a native, our measure of access to native networks, increases the probability of immigrant employment (Furtado and Theodoropoulos 2009). Next, we examine the likely causes of this relationship, focusing on the role of networks.

Most of the immigration literature measures association with natives using immigrant residential patterns (for example, Borjas 1995, Edin, Fredriksson and Aslund 2003, and Beaman 2009). However, residence in an ethnic enclave does not necessarily imply association with coethnics. Given the relatively low costs of transportation and communication, an immigrant living in an enclave may associate mainly with natives at work and in social settings, while an immigrant residing a considerable distance from an enclave may have his social circle comprised mostly of other immigrants. Marriage to a native, however, necessarily implies association with at least one native. Moreover, since marriage to a native can be viewed both as a cause and an effect of association with natives more generally, we argue that it can be used as a measure of the proportion of natives within an immigrant's social network. 
Using marriage market conditions as instruments, Meng and Gregory (2005) and Meng and Meurs (2009) find that marriage to a native increases earnings of immigrants in Australia and France, respectively. Kantarevic (2004) fails to find a marriage to a native earnings premium in the U.S. after accounting for selection. However, using similar data, Furtado and Theodoropoulos (2009) show that marriage to a native increases employment probabilities of immigrants. The seemingly contradictory findings for the U.S. can be reconciled if marriage to a native increases employment probabilities of low-wage workers more than high-wage workers. Moreover, using U.S. data, Goel and Lang (2009) find that although ethnic networks tend to increase the arrival rate of job offers, they do not change the distribution of wage offers. If, as we argue below, the returns to marrying a native stem from networks, then it is entirely plausible that marriage to a native increases employment probabilities without affecting wages among those employed.

Using approaches similar to those in Meng and Gregory (2005) and Furtado and Theodoropoulos (2009), we show that marriage to a native indeed increases employment rates of male immigrants arriving in the U.S. at age 18 or below. ${ }^{1}$ To correct for any possible endogeneity bias, we instrument for marriage to a native using the proportion foreign born of the females in the immigrant's MSA and age group as well as country of origin-specific sex ratios in age group. We find that positive selection into marrying a native is not likely to be a problem since the IV estimates are larger but empirically indistinguishable from the OLS estimates. Supplementary analyses suggest that, if anything, our IV estimates underestimate the true returns to marrying a native.

The main contribution of this paper is to examine whether networks acquired through marriage can explain the marriage to a native premium. To do this, we start by showing that the

\footnotetext{
${ }^{1}$ We focus on this group of immigrants because their participation in the U.S. marriage market is clearer.
} 
gains to marrying a native are not merely reflective of the institutional benefits arising from marriage. One potential source of the marriage to a native premium is that it brings with it the legal right to work for the many unauthorized immigrants in the United States. To examine this issue, we test whether immigrants that are unlikely to have ever been undocumented workers, based on their observable characteristics, experience a marriage to a native premium. We also compare the returns to cohabitation with a native as opposed to marrying a native since the former cannot bring with it the legal right to work. In all cases, we find that sharing a household with a native increases employment probabilities, suggesting that the relationship cannot be explained solely by legal status.

Another possible marriage-specific explanation is that native spouses have characteristics which aid in immigrants' job searches. For example, they may have better job search skills or greater knowledge of the labor market, both of which would enable them to help their spouses find work. To examine this issue, we add to both the OLS and IV specifications spouse labor market and education variables which may enhance the ability of a spouse to aid in her husband's job search. While these characteristics do influence employment rates, again the coefficient on marriage to a native remains positive and significant suggesting that there is another mechanism at play.

Finally, to examine whether the different networks acquired through marriage play an important role in an immigrant's job search process, we assume that when an immigrant marries, he gains access to a network with relatively more natives if he marries a native than if he marries another immigrant. This implies that marriage to a native should increase employment probabilities more for those immigrants who stand to gain more from a native network. Our main 
strategy involves identifying the immigrant populations with the most to gain from native networks and empirically examining whether they in fact experience greater returns to marrying a native. ${ }^{2}$ Our network results can be summarized as follows. First, the larger is the difference between native and immigrant employment rates within an immigrant's age and metropolitan area, the larger is the increase in the probability of employment for immigrants that marry natives. Second, the gains to marrying a native are greater for people who are the most likely to use personal contacts in job search, namely, those with lower levels of education. Lastly, immigrants surrounded by other immigrants from the same country of origin do not increase their employment probabilities by as much when they marry natives. In fact, marriage to a native can decrease employment rates for immigrants living in areas with large enough same-ethnicity populations. All of these results are consistent with theoretical predictions and empirical findings established by the network literature. ${ }^{3}$

We also examine the effect of marriage to a native on a different set of outcomes. Consistent with network members providing referrals and sharing information about jobs, we find that immigrants married to natives tend to work in occupations with more natives. We also find that marriage to a native increases the probability of being in paid employment more than the probability of self-employment. This may not be surprising since many of the businesses owned by the foreign born cater to immigrants and so a network comprised mainly of immigrants may be relatively more useful than native networks for those considering entrepreneurial opportunities. Although these tests may be inconclusive in themselves, taken together, we view

\footnotetext{
${ }^{2}$ We note that we are not directly measuring networks in the manner of Lee (2007) and Bramoullé, Djebbari and Fortin (2009). Instead, we provide evidence consistent with the role of networks in explaining the employment benefits of marriage to a native.

${ }^{3}$ Participation in networks with more employed members is associated with higher employment probabilities (Calvó-Armengol and Jackson 2004, Blau and Robbins 1990). Low skill workers are more likely than high skill workers to use personal connections when searching for jobs (Ioannides and Datcher Loury 2004). Larger networks are better able to generate job offers for network members (Gang and Zimmermann 2000).
} 
our results as providing rather strong support for the role of social assimilation in explaining the economic assimilation of immigrants.

The remainder of the paper is organized in the following way. Section 2 describes the data. Section 3 examines the relationship between marriage to a native and employment rates of immigrants in both OLS and IV contexts. In Section 4, we examine the marriage-specific mechanisms through which marriage to a native might increase employment probabilities. In Section 5, we present and test a series of hypotheses related to the network benefits of marrying a native. Section 6 concludes.

\section{The Data}

Our analysis employs the 5 percent sample of the 2000 U.S. Census as reported by the Integrated Public Use Microdata Series (IPUMS, Ruggles et al. 2004). Since our interest lies in comparing the labor market returns to marrying a native as opposed to an immigrant, rather than estimating a return to marriage in general, we take the marriage decision as given and keep only married individuals in our sample. ${ }^{4}$ Because of the difficulties in interpreting labor market outcomes of females and students, we restrict our sample to foreign born males between the ages of 18 and 62 that are not enrolled in school. ${ }^{5}$ We keep only the immigrants that arrived in the U.S. before the age of 19 since they are most likely to have been exposed to the U.S. marriage

\footnotetext{
${ }^{4}$ There is a large literature documenting and explaining the marital wage premium (see Antonovics and Town 2004). Consistent with this literature, we found that, conditional on observables, immigrants married to other immigrants were about four percentage points more likely to be employed than never-married immigrants, but immigrants married to natives were almost ten percentage points more likely to be employed than never-married immigrants.

${ }^{5}$ Given that immigrant-immigrant divorce rates are typically lower than immigrant-native divorce rates (Kalmijn, de Graaf and Janssen 2005), it is possible that the results in the paper are driven by selection into marriage. Following Qian and Lichter (2007), we ran our primary specifications on immigrants younger than age 35 in order to limit the degree of selectivity. Results were robust.
} 
market. ${ }^{6}$ An immigrant is defined to be anyone who is born outside of the 50 U.S. states but not born to U.S. parents. Individuals born in U.S. territories and outlying areas are dropped from the sample. For ease of interpretation, we also drop unpaid family workers. Lastly, we exclude individuals that report more than one race category. The race categories used in the analysis are non-Hispanic White, non-Hispanic Black, Asian, Hispanic and other race. The final sample consists of 75,139 observations.

Our intermarriage variable takes the value of one if the immigrant is married to a native and zero if he is married to another immigrant. We concede that marriage to a native does not necessarily imply marrying someone with a different cultural background. However, as can be seen in Table 1, about three quarters of the immigrants who marry other immigrants share the same ancestry with their spouse. Meanwhile, of the immigrants who marry natives, only about 30 percent share the same ancestry. Because of its subjectivity, interpretation of the responses to the ancestry question in the Census is difficult (Farley 1990), but we maintain that association of natives, regardless of their ethnic background, is a good measure of an immigrant's association with natives more generally.

Table 1 also presents descriptive statistics of the other variables used in the analysis. Immigrants married to other immigrants are less likely to be employed than immigrants married

\footnotetext{
${ }^{6}$ Readers may wonder whether the findings in this paper extend to immigrants that arrive in the U.S. as adults. For exploratory purposes, we ran the main empirical specifications on all immigrants. All of the main results in the paper were robust. It is difficult to interpret the effect of marriage to a native for this sample since there might be a correlation between travelling to the U.S. as a married couple and employment rates upon arrival which is unrelated to native contacts. Although we would have liked to include all immigrants that arrived before marriage, information on age at first marriage is not available in the 2000 and 1990 Censuses. Some earlier Census datasets have information on age at marriage, but because the composition of immigrants in the U.S. has changed so much in the past few decades, we prefer to use the more recent data. We did, however, restrict our analysis to immigrants that arrived in the U.S. between the ages of 16 and 18. Although there was not enough age variation to precisely estimate the IV coefficients, the other results were robust.
} 
to natives. ${ }^{7}$ This should not be surprising given that immigrants in cross-nativity marriages are more educated, more fluent in English, and have resided in the U.S. for more years. Whites are more likely than racial minorities to marry natives. There is also substantial variation in endogamy rates across ethnic groups. Of the ten ethnic groups with the greatest representation in the U.S., Canadians are the most likely to marry a native with an exogamy rate of 83 percent while the Vietnamese are the least likely with an exogamy rate of eight percent. ${ }^{8}$

\section{The Effect of Marriage to a Native on Employment of Immigrants}

\subsection{Ordinary Least Squares Analysis}

Ordinary least squares analysis offers an initial look at the effect of marriage to a native on immigrant employment rates. The primary empirical specification in the analysis is

$$
E m p_{i a c}=\beta_{1} N_{i a c}+\beta_{2} X_{i a c}+\gamma_{a}+\gamma_{c}+\varepsilon_{i a c}
$$

where $E m p_{i a c}$ is equal to one if immigrant $i$ of age $a$ from country of origin $c$ is employed and zero otherwise, and $N$ is an indicator variable for whether the immigrant is married to a native. The vector $X$ consists of human capital and assimilation controls described below. Age fixed effects are denoted $\gamma_{a}$ while $\gamma_{c}$ denotes country of origin fixed effects and $\varepsilon$ is a random error term. The age fixed effects capture any linear or non-linear effects of experience on employment. The country of birth fixed effects are included because immigrants from certain countries may find it easier to both marry natives and find or keep jobs. For example, immigrants from Canada and Australia may have better employment outcomes in the U.S. and be more likely to marry natives than immigrants from non-English speaking countries.

\footnotetext{
${ }^{7}$ An immigrant is considered employed if in the previous week, he worked for at least one hour for pay or profit, at least 15 hours as an unpaid family worker, or was temporary absent from a job because of illness or vacation.

${ }^{8}$ The other top ten sending countries are Mexico, El Salvador, Cuba, Dominican Republic, Italy, Germany, Korea, and the Philippines. We do not include endogamy rates by country of origin in the table because of space considerations.
} 
As can be seen in Table 2, marriage to a native is associated with about a ten percentage point increase in the probability of employment, but adding age, region, and country of origin fixed effects results in a three percentage point drop in the estimated effect. The next specification includes the basic controls used in any employment regression as well as assimilation controls which cannot be affected by marriage decisions. We include dummy variables measuring educational attainment, race, and whether the immigrant is a veteran or disabled. To measure assimilation, we include in the specification years since migration as well as a dummy variable equal to one if the immigrant has arrived within the previous five years. All of the coefficients on the controls in the model shown in column 3 of Table 2 have the expected signs, and marriage to a native is associated with a 4.9 percentage point increase in the probability that an immigrant is employed.

There are other assimilation variables available in the data which may operate both as controls for the level of assimilation reached before marriage and as mechanisms through which marriage to a native affects employment rates. For example, English fluency increases the probability of marriage to a native, but marriage to a native surely improves language ability. Similarly, less assimilated immigrants are more likely to reside in ethnic enclaves and are therefore less likely to encounter native potential spouses. If ethnic enclaves have fewer economic opportunities, then it is important to include some measure of the size of the immigrant group residing within close geographic proximity in the regressions. At the same time, marriage to a native may result in a move away from an ethnic enclave. If this is a mechanism through which marital exogamy increases employment rates, then it is best to omit this variable from the empirical specification. ${ }^{9}$

\footnotetext{
${ }^{9}$ We use 'marital exogamy' interchangeably with marriage to a native.
} 
In column 4, we add to the model a measure of self-reported English fluency (an indicator variable equal to one if the immigrant reports speaking either only English or English very well), the percentage of the immigrant's MSA with same country of birth, and whether the person lives in a central city. When these variables are added, the estimated exogamy coefficient falls by almost 20 percent. ${ }^{10}$ We note, however, that controlling for these assimilation variables limits the avenues through which marriage to a native can increase immigrant employment rates in our model. Given that English fluency and residence away from ethnic enclaves increase employment probabilities, these estimates can be regarded as underestimates of the total effect of marriage to a native.

Another potential concern arises if immigrants residing in metropolitan areas with worse economic conditions are less likely to marry natives. To address this issue, we control for nativeborn age-specific unemployment rates. By using native-born unemployment rates, we avoid a potential reverse causality problem. Because unemployment rates in an MSA could vary by experience level, we construct unemployment rates which vary by MSA as well as age. Although the native unemployment rate is associated with lower immigrant employment probabilities, the inclusion of the variable has no effect on the marriage to a native coefficient. In the final specification, shown in column 5, marriage to a native leads to a four percentage point increase in the probability of employment. ${ }^{11}$

\footnotetext{
${ }^{10}$ Because our English fluency variable is based on self-responses, it may not accurately measure people's speaking ability. To address this issue, we ran regressions separately on immigrants from English speaking and non-English speaking countries, defined according to Bleakley and Chin (2010). Although the effect of marriage to a native was larger for immigrants from non-English speaking countries $(\beta=0.041, \mathrm{p}=0.000)$, the coefficient was positive and statistically significant $(\beta=0.029, \mathrm{p}=0.010)$ even for those who most probably had little to gain from native spouses in terms of language acquisition. This suggests that there must be mechanisms other than English fluency through which marrying a native increases the employment probabilities of the foreign born.

${ }^{11}$ Because immigrants from the same country but different cohorts could have very different unobservable characteristics, we added to the model a full set of country of origin dummy variables interacted with years in the United States. The coefficient on marriage to a native remained positive and significant $(\beta=0.040, p=0.000)$. For simplicity, we chose not to include these interactions in our preferred specification. Given the likely importance of
} 


\subsection{Instrumental Variables Analysis}

Although our rather extensive list of controls precludes many of the sources of bias on the intermarriage coefficient, one may still be concerned that immigrants that marry natives have unobservable characteristics correlated with both economic outcomes and the probability of marrying a native. For example, immigrants that are more assimilated may be more likely to marry natives and have gainful employment. Alternatively, it may be that conditional on our various human capital and assimilation controls, it is the most hard-working immigrants that marry other immigrants. After all, despite lower levels of education and lack of English fluency, immigrant males have higher labor force participation rates than native males (U.S. Census Bureau 2000). Comparing employment rates of natives to immigrants arriving before the age of 19, we find that conditional on observables, immigrants have higher employment rates than natives. Duncan and Trejo (2010) explain why, conditional on education, immigrants have higher employment rates than natives with a model in which unemployed immigrants return to their home countries. For our purposes, because return migration following unemployment may only be feasible for immigrants married to other immigrants, the resulting sample of intermarried immigrants may have spuriously lower employment probabilities. Moreover, if immigrants have stronger work preferences than natives, they may match most efficiently in the marriage market with similarly ambitious immigrants.

Building on the identification strategy of Meng and Gregory (2005), we correct for endogeneity by instrumenting for intermarriage using two measures of marriage market conditions. Our first instrument is the share of females in the immigrant's age group residing in his MSA that is foreign born. Age groups are created in nine year intervals. Because females

religion in intermarriage decisions, we would have also liked to explore the role of religion in our analysis. Although our country of birth fixed effects partially account for religion, we could not do anything further since the U.S. Census does not collect information on religion. 
tend to marry males who are two years their senior, the mean age within the interval is two years less than the age of the male immigrant. For example, for an immigrant male who is 25 years old, we calculate the percentage foreign born of the females in his MSA who are between the ages of 19 and 27 . Theory suggests that as the percentage of immigrant females increases in an MSA-age group, immigrant males are less likely to encounter and therefore marry natives regardless of person-specific characteristics.

Our second instrument makes use of varying sex ratios within country of birth-age group cells. We define the sex ratio for a particular male to be the number of females divided by the number of males in that immigrant's country of birth-age group. Again, we define age groups using nine year intervals taking into account the fact that wives are typically two years younger than their husbands. Thus, for a 25 year old Mexican immigrant, we construct the sex ratio by dividing the total number of Mexican females between the ages of 19 and 27 by the total number of Mexican males between the ages of 21 and 29. As the sex ratio increases, there is less competition among males for same country of origin foreign born females and so fewer immigrant males should marry natives. We note, however, that because country of origin fixed effects are included in all specifications, identification comes from cross-age variation in sex ratios only.

Our identification strategy rests on the assumption that these instrumental variables only affect employment probabilities through their effect on marriage choice. Although a few potential problems with this assumption may come to mind, our control variables should assuage the most obvious concerns. For example, immigrants in general, but especially unmarried male immigrants, may be attracted to cities with better economic opportunities. We note, however, 
that MSA-age specific native unemployment rates are included in the main specification thus mitigating this concern.

Potentially problematic for our first instrumental variable (percent foreign-born) is the possibility that immigrants residing around a large number of other immigrants are less assimilated and so less likely to be employed. Although we control for English-speaking ability, nonverbal forms of communication may be easier in ethnic enclaves. Also, festivals and social clubs are more likely to arise in areas with a number of same-ethnicity inhabitants. The key in all of these examples is that benefits arise when immigrants are around others from the same country of origin. Because we include a control for the size of the immigrant's ethnic group in his MSA, identification from the percent foreign instrumental variable arises from variation in the size of the female foreign born population in the immigrant's age group and MSA, conditional on the number of immigrants from his own ethnic group in his MSA. This variation is less likely to be problematic.

Column 1 of Table 3 presents first stage regression results for the main specification used in the paper. Standard errors in the IV regressions are clustered on MSA-age-country of birth cells. We find that a ten percentage point increase in the percent of females in an immigrant's ageMSA group that is foreign decreases the probability that he marries a native by almost five percentage points. Also, as the number of females per male increases by one, the probability that an immigrant male marries a native decreases by over six percentage points. The coefficients on both instruments are individually significant at the $1 \%$ level of significance. As can be seen in Table 3, the F statistic for excluded instruments far exceeds the commonly used threshold of 10. 
Second stage IV results, shown in the second column of Table 3, suggest that marriage to a native increases immigrant employment rates by about six percentage points. ${ }^{12}$

With a p-value of 0.511 , a Hausman test does not reject the equality of the OLS and IV estimates, but it is noteworthy that the IV point estimate is larger in magnitude than the OLS point estimate. We interpret this as evidence that conditional on observable characteristics the immigrants that marry other immigrants are positively selected on employment probability. Nevertheless, it is useful to consider how the instruments may be correlated with the error term in the employment equation if there is any correlation at all. One potential concern is that immigrants living in areas with large foreign born populations face worse labor market conditions than those living in areas with relatively few immigrants. Although we control for unemployment rates in the regressions, the average unemployment rate may mask labor market conditions in the industries in which immigrants typically work. To examine this issue, we computed for each MSA unemployment rates in the occupations that employ many immigrant males: manufacturing, agriculture, and construction. Adding these unemployment rates as controls to the IV specification actually increases our estimates of the effect of marriage to a native, suggesting that there are more immigrants in areas with lower unemployment rates in immigrant dominated industries. ${ }^{13}$ This is consistent with findings in the immigration literature

\footnotetext{
${ }^{12}$ For some additional justification of the instrumental variables, we performed a simple falsification test using reduced form specifications. If our IVs are correlated with employment rates for reasons unrelated to marriage decisions, then they should impact employment rates of both married and never-married immigrants. On the other hand, valid IVs will predominantly affect the employment patterns of married immigrants. Estimation results, available upon request, show that while percent foreign has a negative and statistically significant estimated effect on employment probabilities of married immigrants, it has no statistically significant impact on never-married immigrants. The sex ratio variable, on the other hand, has no statistically significant impact on both married and single immigrant males. We interpret these reduced form results as suggestive evidence of the exogeneity of our instruments.

${ }^{13} \mathrm{We}$ also ran a regression controlling for the growth in the percentage of the employed population in these three industries between 1990 and 2000, in case the most employable immigrants are especially responsive to growth rates when making migration decisions. Again, the marriage to a native coefficient was slightly larger than that in our baseline IV model. A similar pattern resulted from controlling for unemployment rates by skill level (measured by education and age). All of these regression results are available upon request.
} 
suggesting that immigrants respond quickly to labor market incentives when making location decisions (Card 2001). ${ }^{14}$

For further evidence that, conditional on observables, immigrants living in MSAs with large immigrant populations are more likely to be employed, we consider the relationship between our instrumental variables and completed years of schooling. As can be seen in the third column of Table 3, the percent foreign born and sex ratio instruments are positively related to years of schooling. Thus, given that both the percent foreign and sex ratio IVs are negatively related to the probability of marrying a native, if unobserved characteristics such as diligence and ambition are positively correlated with schooling, our IV estimates will underestimate the true effect of marriage to a native.

For a final piece of evidence that our IV estimates are not overestimating the effect of marriage to a native, we examine the relationship between our instruments and the likelihood that people in our sample have severe disabilities. Since disability rates are unlikely to be affected by social interactions, any relationship between our instruments and disability rates might suggest that our instruments do not satisfy the exclusion restrictions. As can be seen in Column 4 of Table 3, the coefficients on both of the instrumental variables are very close to zero and statistically insignificant. This should not be surprising despite the positive and statistically significant relationship between the instruments and years of schooling since, unlike the highly

\footnotetext{
${ }^{14}$ The fact that immigrants are responsive to labor market conditions makes it difficult for researchers to estimate the wage effects of immigration in so-called area studies. One often-used solution to this problem is to construct an instrument for immigration based on ethnic networks and total immigrant flows from particular countries of origin (Card 2001). We used this predicted immigrant share based on networks to instrument for marriage to a native. Just as we might have expected, the instrument is negatively related to the probability of exogamy, and the estimated marriage to a native coefficient using this instrument is even larger than the coefficient estimated using our marriage market IVs.
} 
educated, the severely disabled are not likely to be very responsive to changes in labor market conditions across MSAs. ${ }^{15}$

All of these findings suggest that if the percent foreign born and sex ratio variables are positively correlated with labor market conditions. Given the negative relationship between the instruments and the probability of marrying a native, this implies that the instrumental variables regressions will overestimate the return to marrying a native. Since the OLS estimates re even more conservative than the IV estimates, we will err on the side of caution by conducting the remainder of the analyses in the paper using ordinary least squares. We turn now to the mechanisms through which marriage to a native may increase immigrant employment rates. In order to establish the role of networks, we start by showing that legal status and citizenship rights as well as spouse characteristics cannot explain the entire marriage to a native premium. Next, we provide evidence of network effects by highlighting patterns in the data which are consistent with hypotheses established by the network literature.

\section{Marriage-Specific Mechanisms}

\subsection{Legal Status Acquired Through Marriage}

One may believe that returns to marrying a native arise solely from the legal status and citizenship rights unauthorized immigrants acquire through these marriages. For the approximately 9.3 million unauthorized immigrants residing in the United States--26 percent of the foreign-born population (Passel, Capps and Fix 2004)--legal status can expand employment

\footnotetext{
${ }^{15}$ Our particular measure of disability is whether the respondent has any physical or mental health condition that "makes it difficult for the person to take care of his or her own personal needs, such as bathing, dressing, or getting around inside the home." The Census has a more general question of disability which asks whether the person has "any lasting physical or mental health condition that causes difficulty working, limits the amount or type of work they can do, or prevents them from working altogether." We believe that immigrants with weak employment prospects, potentially as a result of their marriage decisions, are more likely to answer yes to this broad question. After all, there is a vast literature showing that participation in disability programs are very responsive to economic conditions (e.g. Black, Daniel and Sanders 2002). Census responders are unlikely to claim to have a severe disability in response to poor employment prospects.
} 
possibilities to include stable jobs requiring genuine work authorization documentation. To examine whether this can explain the entire marriage to a native premium, we take two different approaches.

To start, we would have liked to compare the returns to marrying a native for immigrants legally allowed to work in the U.S. upon arrival, such as refugees and those with non-spousal family visas, to those who arrived in the U.S. without a valid visa. If the right to work legally were the sole mechanism through which marriage to a native increases employment rates of immigrants, we would observe no marriage to a native premium for immigrants authorized to work upon arrival but a large premium for those arriving without authorization to work. Unfortunately, this data is not available from the U.S. Census. Instead, we compare the returns to marrying a native for those immigrants whose characteristics most closely resemble the characteristics of unauthorized immigrants to those who are least likely to have ever been unauthorized.

As discussed in Passel and Cohn (2009), unauthorized immigrants in the U.S. come disproportionately from Mexico and Central America, reside in California, Texas, Florida and New York, and are significantly less likely than natives to have a high school degree. ${ }^{16}$ Thus, as a first approach, we compare the marriage to a native coefficient for a sample of immigrants with these characteristics to the coefficient for a sample of immigrants that do not have any of these characteristics. The results shown in the first panel of Table 4 suggest that although the probable unauthorized immigrants have a greater return to marrying a native than the probable authorized immigrants, the return to marrying a native remains positive and highly significant even for the foreign born that are least likely to have ever been undocumented.

\footnotetext{
${ }^{16}$ About 70 percent of unauthorized immigrants in the U.S. are from Mexico or Central America. More than half live in California, Texas, Florida or New York and 47 percent of unauthorized immigrants have less than a high school education (Passel and Cohn 2009).
} 
We also compare the marriage market returns of Mexicans to Puerto Ricans since over half of all undocumented immigrants in the U.S. are Mexican (Passel and Cohn 2009) and Puerto Ricans are legally allowed to work in the country. Again, although these two groups have similar cultures and average education levels, a Puerto Rican would not gain the right to work legally from marrying a native while a Mexican may. As can be seen in second panel of Table 4, for both groups, marriage to a native is associated with a positive and significant increase in the probability of employment.

Our next approach compares the returns to marrying a native to the returns to cohabiting with an opposite sex native. In both cases, an immigrant would have substantial contact with a native and her contacts, but only through marriage would he gain legal status. The last panel of Table 4 presents estimated coefficients from regressions run on married and cohabiting couples separately. Results suggest that even though the increase in the probability of employment is slightly higher for those marrying a native than it is for those cohabiting with one, sharing a household with a native as opposed to an immigrant results in a positive and significant increase in the probability of employment in both samples. We do not interpret the differential between the marriage and cohabitation coefficients as clear evidence of the role that the right to legally work plays in explaining the marriage to a native premium. Zhang and Song (2007) find that the average marriage lasts 12 years while cohabiting unions last approximately three years. The slightly larger return to marrying a native could simply reflect the fact that these immigrants have had many more years to accrue the benefits of sharing a household with a native. Nevertheless, the positive and significant return to cohabiting with a native suggests that the gains to marrying a native do not simply indicate a return to legal status. There must be another 
mechanism through which marriage to a native increases employment probabilities of immigrants.

\subsection{Spouse Characteristics}

Another potential explanation for why marriage to a native increases immigrant employment rates is related to the characteristics of native spouses. For example, since native wives are more likely to work and have higher earnings, they may be better able to support longer job searches for their husbands, thereby decreasing immigrant employment rates. On the other hand, spouses that work outside of the home may have more information about job openings and how to search for job openings, thus implying an increase in immigrant employment rates. Also, labor market participation of wives may signal greater household preferences for market goods which would be correlated with an increase in labor force participation rates of husbands.

It is also important to account for differences in spouse's human capital. If native wives have more years of schooling, they may be better qualified to aid in their husbands' job searches. Given the relationship between education and the utilization of formal job search methods educated spouses may enable their husbands to conduct more formal job searches. For example, they may edit resumes and job applications thus increasing the probability of an interview. This may be especially beneficial for immigrants given that it takes approximately 12 years for immigrants in the U.S. to use the same information during job search as natives (Daneshvary $e t$ al. 1992).

Table 5 shows regression results for both OLS and IV models which include these spouse characteristics. All specifications include the controls used in the final specification of column 5 in Table 2. Spouses that do not work and therefore have zero wage income were coded as having an income of 0.001 so that they would not be dropped from the analysis in specifications which 
control for the log of spousal earnings. A dummy variable indicating that this change was made is included in all specifications. OLS and IV coefficients from models without spouse characteristics are reproduced in Table 5 for convenience. In columns 2 and 4 , spouse characteristics are added to the OLS and IV models respectively. Consistent with traditional labor supply models, an increase in spousal earned income--defined as pre-tax wage and salary income--decreases the probability of employment. However, conditional on earnings, spouse's employment increases employment rates of immigrants. This may be because employed wives, regardless of nationality, are better able to aid their spouses in the job search process. Spouse education also increases immigrants' employment probabilities. When interpreting the spouse human capital coefficients, caution is necessary since, because of assortative mating on education and ability in the marriage market, spouse's education may absorb unobserved variation in the immigrant's own ability. When spouse characteristics are added to both the OLS and IV models, the coefficients on marriage to a native remain positive and statistically significant.

It is interesting to note that although the OLS marriage to a native coefficient decreases when spouse characteristics are added to the model, the IV coefficients are remarkably similar regardless of whether spouse characteristics are included. This suggests that the spouse characteristics are actually measuring unobserved ability since IV models generate consistent estimates regardless of whether controls for ability are included in the model.

Readers may be concerned that these spouse characteristics are just as endogenous as spouse's nativity. At least as many instruments as spouse characteristics are required in order to properly address this issue. Exploiting the same type of variation that is used to construct the instruments for spouse nativity, we constructed instruments for the other spouse characteristics in 
the following way. First, we compute for each MSA-age group and spouse characteristic the average values of these characteristics for immigrant and native females. Next, for each immigrant male in the sample, we construct the predicted probability that he marries a native using the estimated first stage coefficients shown in column 1 of Table 3. Thus, for example, the instrument for spouse's earnings is the weighted average of immigrant and native mean earnings where the weights are the predicted probabilities of marrying an immigrant and native respectively. As seen in column 5 of Table 5, when this full set of instruments is used in the model, the estimated coefficient on marriage to a native remains about the same. The estimated effects of the other spouse characteristics, however, are no longer statistically significant.

Again, we conclude that there must be another mechanism through which marriage to a native affects labor market outcomes of immigrants. In the following section, we examine the role of networks. We note, however, that many of our measures of spouse characteristics may already capture network effects. For example, high education spouses are more likely to have high education contacts. Given that nativity of spouse remains significant even when spouse's education is included in the model, we argue that the proportion of immigrants in one's network has its own independent effect even conditional on the proportion of educated members of one's network.

\section{The Role of Networks}

In this section, we present several pieces of evidence suggesting that the gains from marriage to a native occur at least partly because of the contacts acquired through marriage. Most of the network literature characterizes a person's network using some function of the number of racial, ethnic, or language minorities residing within close geographic proximity. This paper uses marriage decisions as opposed to residential decisions to study the role of networks. We assume 
that all people acquire new contacts upon marriage but that networks gained from marriage to a native contain relatively more natives than networks gained from marriage to an immigrant. Our main empirical approach relies on identifying the immigrants with the most to gain from native contacts and testing whether they, in fact, have larger marriage to native premiums.

\section{$5.1 \quad$ Network Hypotheses}

There are several reasons why having employed contacts may increase employment probabilities. Utility from leisure may be increasing in the number of a person's acquaintances that do not work (Hellerstein, Neumark and McIrney 2008). This may be true both because friends make leisure more enjoyable and because any unemployment stigma most probably decreases as the number of people not employed increases. Because natives have higher average employment rates, exposure to work norms within native networks may result in more job search effort among immigrants seeking employment.

Potentially more important, however, is the role that native contacts may play in providing referrals and sharing job opening information within the network. ${ }^{17}$ Since the employed have more direct information about jobs at their place of employment, the quality of the information they share is likely to be superior. Because recommendations reflect on themselves, current employees of a firm have an incentive to recommend only applicants that are likely to be successful at their firms (Granovetter 2005). This may be why applicants with internal references are more likely to receive job offers and accept them (Blau and Robbins 1990). If the matches between employer and employee are particularly good when arranged through personal

\footnotetext{
${ }^{17}$ Connection to a network with a greater proportion of employed members will tend to generate more information about job openings both because the employed are less likely to apply for the jobs themselves and because fewer unemployed members of the network implies less competition for information (Calvó-Armengol and Jackson 2004). The literature suggests that anywhere from 30 to 60 percent of all job openings are filled using informal methods (Bewley 1999).
} 
recommendations, we should also expect applicants with internal references to have longer firm tenures. For all of these reasons, we can expect that in markets where natives have significantly higher employment rates than immigrants, marriage to a native will lead to relatively higher employment rates for immigrants.

Hypothesis 1: Marriage to a native increases employment rates more when the difference between average native and immigrant employment rates is larger.

In order to test this hypothesis, we include in the model an interaction between marriage to a native and the difference between average native employment and immigrant employment. We define markets based on the immigrant's MSA and age. If our hypothesis is correct, the coefficient on the interaction will be positive.

An often cited stylized fact established in the network literature is that more educated jobsearchers are less likely to make use of personal connections in their job searches (see Ioannides and Datcher Loury 2004; Hellerstein, McInerney, and Neumark 2009). If it is true that networks are more important for those with less schooling and native acquaintances provide more useful job information, then marriage to a native should result in smaller increases in the probability of employment for those with more education. That is,

Hypothesis 2: Marriage to a native increases employment rates less for immigrants with more education.

To test this hypothesis, we add to our model a series of interaction terms between marriage to a native and the education dummy variables. We expect the coefficients on the interactions of marriage to a native with higher level education dummies to have negative coefficients.

For our third hypothesis, we exploit the theoretical prediction and empirical finding that the larger the size of a network, the more useful it is to its members (e.g. Gang and Zimmermann 2000). Members of small, close-knit ethnic communities are likely to already know each other 
and so very few new contacts can be gained from marriage to another immigrant. Even from a simply probabilistic standpoint, larger, more established ethnic communities are more likely to have successful members in many different occupations and so connection to these communities should prove more useful. ${ }^{18}$ Another common feature of networks is their tendency to exhibit threshold effects, which occur when the actions of others have little impact on behavior until a certain number or percentage of others adopts the behavior (Granovetter 1978, Calvó-Armengol and Zenou 2005). In the context of this study, participation in ethnic networks may only be useful for generating job offers when the size of the ethnic group exceeds some specific critical value. For smaller ethnic groups, marriage to a native and the resulting participation in native networks may be more beneficial. More formally,

Hypothesis 3: Marriage to a native has a positive effect on employment rates unless the size of the immigrant's ethnic group living within close geographic proximity exceeds a certain critical value.

To test this hypothesis, we include in the model a set of interactions between marriage to a native and splines representing various ranges of the ethnic group's size. If threshold effects are important, then the coefficients on these interactions should be small and insignificant for low ranges, but negative and significant for high ranges.

We turn now to a set of hypotheses relating marriage to a native to a different set of outcomes. First, if members of native networks provide referrals or share information about job openings at their place of employment, then immigrants who participate in native networks should end up working with relatively more natives. That is,

Hypothesis 4: Immigrants that marry natives are more likely to work with a larger proportion of natives.

\footnotetext{
18 See Beaman (2009), Munshi (2003), Patacchini and Zenou (2008) for empirical analyses of the relationship between ethnic group size and labor market outcomes.
} 
Ideally, we would test this hypothesis by examining the effect of marriage to a native on the relative proportion of natives working at the same establishment, in a manner similar to the work of Hellerstein et al. (2009) and Dustmann, Glitz, and Schönberg (2009). Using U.S. and German data respectively, these studies find that minority workers are more likely to have colleagues from their own minority group than other groups. Unfortunately, we do not have the matched employer-employee data necessary to do this type of analysis. Instead, we calculate for each employed immigrant male in our sample, the proportion of people within his occupation and MSA that are native-born. If native networks generate more successful job matches than ethnic networks, then immigrants married to natives will be in occupations with relatively more natives.

Finally, we consider how connections to natives differentially impact immigrants' gains to self-employment as opposed to wage employment. According to Borjas (1986), many of the immigrants that are self-employed own businesses which cater to their ethnic communities. Thus, connection to a predominantly native network may not be especially useful for starting a business with an ethnic focus. Also, immigrants from countries with high self-employment rates tend to have higher rates of self-employment (Yuengert 1995, Fairlie and Meyer 1996), with certain ethnic communities specializing in specific types of businesses (see Patel and Vella 2007 as well as Munshi and Wilson 2008 for examples). Thus, at least for certain businesses or certain ethnic groups, connection to an ethnic network as opposed to a native network may be more valuable for immigrants considering self-employment. We state the hypothesis more formally below:

Hypothesis 5: Marriage to a native increases the probability of paidemployment more than it increases the probability of self-employment.

We test this hypothesis simply by comparing the effect of marriage to a native on selfemployment and wage-employment. 


\section{$5.2 \quad$ Network Test Results}

Table 6 presents OLS results from the first three network tests, both when adding the interactions of interest one at a time and when including them all at once. ${ }^{19}$ The full set of control variables including spouse characteristics variables was included in all specifications. Consistent with Hypothesis 1, the first column of Table 6 shows that the coefficient on the interaction between marriage to a native and the difference between native and immigrant employment rates is positive and significant. This suggests that when the additional native contacts gained from marriage to a native are more likely to be employed, the gains to marrying a native are larger. More specifically, for every ten percentage point difference in the average employment rate between natives and immigrants in MSA-age group cells, immigrants that marry natives increase their probability of employment by an additional 0.9 percentage points.

Table 6 also provides support for Hypothesis 2. The results shown in column 2 suggest that while immigrants with less than a high school degree increase their probability of employment by 3.4 percentage points by marrying a native, a college graduate experiences only a 0.6 percentage point increase. A potential explanation for this is that firms hiring college graduates typically use more formal recruitment methods and so personal connections acquired through marriage are less useful for college graduates. This is a particularly strong test because ethnic networks should prove relatively more useful for immigrants with lower education levels. Immigrants with very high levels of education relative to their groups are likely to be over-

\footnotetext{
19 We explored models which tested our network hypotheses while instrumenting for marriage to a native. Unfortunately, because many of the interactions used in the tests are constructed from variables that are closely related to our instruments, there is not enough variation in the data to convincingly identify the coefficients of interest. Since a Hausman test could not reject the equality of the IV and OLS coefficients, we favor the OLS coefficients regardless. Ideally, we would also instrument for the network variables, such as native-immigrant employment differentials, since they are also choice variables. Unfortunately, we were not able to come up with separate instruments for these variables which would satisfy the necessary exclusion restrictions.
} 
qualified for the job openings about which typical ethnic network members have knowledge. If ethnic networks are more advantageous than native networks for those with fewer years of schooling, then it is quite telling that despite this, college graduates gain less from marriage to a native than high school graduates.

This network test can also be interpreted as evidence that the estimated positive effect of marriage to a native cannot be explained solely by selection. Duncan and Trejo (2010) show that immigrants with less than a high school degree are significantly more likely to be employed than comparable natives, while there are little to no immigrant-native differences for higher skill levels. If we assume that it is the immigrants that are most similar to natives in terms of unobservable determinants of employment that are most likely to marry natives, then we would expect a zero or negative coefficient on marriage to a native for the least skilled immigrants. The fact that returns to marrying a native are highest for the least skilled is thus consistent with a network story but not with a positive selection story.

Next we substitute the size of ethnic group variable with a series of splines. In this way, the effect of an increase in the co-ethnic population is allowed to differ across four different ranges: 0-10, 10-20, 20-30, and above 30. To test Hypothesis 3, we interact each of the splines with the marriage to a native variable. Results in column 3 suggest that although marriage to a native increases employment rates for people living in MSAs with relatively small co-ethnic populations (67 percent of our sample resides in areas with less than 10 percent co-ethnic), it can have a negative and statistically significant effect on the immigrants residing in MSAs with large co-ethnic populations (over 30 percent). This may be because in areas with large ethnic populations, connection to an ethnic network proves more valuable than connection to a native network. We interpret the finding that the negative effects of marriage to a native only come into 
play when the co-ethnic population exceeds 30 percent as suggestive of threshold effects. In Column 4, all of the network interactions are included in the model simultaneously, and the main patterns in the data remain the same.

There are several reasons why one may be concerned about the interpretation of the coefficients on the interactions discussed above. In order to correctly interpret the coefficient on the employment interaction, it is necessary to consider what drives the variation in nativeimmigrant differences in employment rates. One possibility is that average immigrant skill levels in certain cities may be ill-matched with particular industry demands. If this mismatch is due to random fluctuations in either the immigrant population or industry mix within a city, this identification strategy is valid. However, it may also be that in cities where immigrants are less prone to work on average, those immigrants that marry natives are more employable, thus generating a spurious correlation between marriage to a native and employment. For this reason, we turn now to a series of hypotheses with a different set of outcome variables.

By Hypothesis 4, if network participants provide referrals and share information about job opportunities, then immigrants married to natives will end up working in occupations with relatively more natives. Column 1 of Table 7 shows that marriage to a native is associated with a 3.5 percentage point increase in the native born proportion of people in an employed immigrant's occupation residing within his MSA. We view this as only suggestive evidence since causality may run in the opposite direction: Immigrants in occupations with relatively more natives may be more likely to marry natives.

We test Hypothesis 5 by examining the effect of marriage to a native on paid and selfemployment separately within a multinomial logit model. Marginal effects, evaluated at variable means, are reported in columns 2, 3 and 4 of Table 7 . As can be seen in table, marriage to a 
native increases the probability of wage employment by 2.7 percentage points, but has no statistically significant effect on the probability of self-employment. These results are consistent with Georgarakos and Tatsiramos' (2009) findings that marriage to a native decreases the probability that immigrants start a business, but conditional on having started, increases survival times of immigrant-owned businesses. Since, as discussed above, native-born friends and family are more likely to be helpful in generating paid employment probabilities than self-employment, we view our results as suggestive of the role of networks in explaining the marriage to a native premium. If the estimated premium were only a return to unobservable characteristics, then it should not matter whether we consider the effect on paid employment or self-employment. In fact, there is evidence that general ability has a larger effect on the earnings of the self-employed than on the wages of paid employees (Hartog, van Praag and van der Sluis 2008). This implies that, if it were only a return to ability, marriage to a native should increase the probability of selfemployment more than the probability of paid employment. Furthermore, if the dominant explanation for the marriage to a native premium lay in the help provided by native-born spouses in job search, then we may expect the premium to be larger for self-employment given that familiarity with English and U.S. laws should be especially valuable for the paperwork involved in setting up and running a business. Of course the possibility of reverse causality remains since the self-employed may not come in contact with as many natives as those who work for a wage, and so again, we must view this as suggestive evidence.

We end this section by noting that although our tests provide only indirect evidence of networks, taken together, we believe that they provide rather convincing evidence of the role of networks in explaining why marriage to a native increases employment probabilities of immigrants. Our results suggest that native networks are more useful than ethnic networks in 
generating stable employment, at least for the foreign-born arriving in the U.S. at or before the age of 18 .

\section{Conclusions}

This paper explores the relationship between marriage to a native and employment rates of immigrant men. We find, using both least squares and instrumental variables approaches already established in the literature, that marriage to a native increases immigrant employment probabilities. We then extend the literature by examining the mechanisms through which marriage choice affects labor market outcomes. We first show that legal status and spouse characteristics cannot explain the entire marriage to a native premium.

Drawing on theoretical and empirical findings from the network literature, we then examine whether immigrants that stand to gain the most from native contacts in fact have greater returns to marrying a native. For example, since employed contacts are better able to generate job offers than non-employed contacts, we test whether immigrants residing in areas where the foreign born have significantly lower employment rates than natives experience larger increases in employment probability from marriage to a native. Similarly, since personal connections are more useful for generating job offers for the less skilled, we test whether marriage to a native has a smaller impact on employment rates of college graduates. Also, given that ethnic contacts may be more useful than native contacts in areas with large co-ethnic populations, we test whether marriage to a native leads to lower employment rates for immigrants in these areas. We also examine the effect of marriage to a native on the proportion of the immigrant's occupation that is native born and the probability of being self-employed. All of our results are consistent with networks playing a strong role in explaining why marriage to a native leads to higher employment rates. 
The findings in this paper have implications which extend beyond the realm of marriage decisions; they point to the importance of association with natives in the economic assimilation of immigrants more generally. Although residence in ethnic enclaves may aid in the initial adjustment to a new country, our results suggest that on average, native contacts prove more useful than immigrant contacts in acquiring gainful employment. Thus, policies that foster increased association between immigrants and natives, such as busing and vouchers for schoolage immigrants residing in ethnic enclaves, may lead to improved labor market outcomes for the foreign born. Policy-makers may also consider programs which aid in the job search process of immigrants, thereby acting as a substitute for native contacts. Because of the externalities resulting from the acquisition of jobs, any improvements in immigrants' employment rates would then further improve labor market outcomes of other immigrants.

\section{References}

Antonovics, K. and Town, R. (2004). Are all the good men married? Uncovering the sources of the marital wage premium, American Economic Review (Papers and Proceedings), Vol. 94, pp. 317-321.

Beaman, L. A. (2009). Social networks and the dynamics of labor market outcomes: Evidence from refugees resettled in the U.S., Unpublished manuscript.

Bewley, T. F. (1999). Why wages don't fall during a recession? Harvard University Press, Cambridge, MA.

Black, D, Daniel, K. and Sanders, S. (2002). The impact of economic conditions on participation in disability programs: Evidence from the coal boom and bust, American Economic Review, vol. 92, pp. 27-50.

Blau, D. M. and Robins, P. K. (1990). Job search outcomes for the employed and the unemployed, Journal of Political Economy, Vol. 98, pp. 637-655.

Bleakley, H. and Chin. A. (2010). Age at arrival, English proficiency, and social assimilation among U.S. immigrants, American Economic Journal: Applied Economics, Vol. 2, 165-192. 
Borjas, G. J. (1986). The self-employment experience of immigrants, Journal of Human Resources, Vol. 21, pp. 487-506.

Borjas, G. J. (1995). Ethnicity, neighborhoods, and human capital externalities, American Economic Review, Vol. 85, pp. 365-390.

Bramoullé, Y., Djebbari, H. and Fortin, B. (2009). Identification of peer effects through social networks, Journal of Econometrics, Vol. 150, pp. 41-55.

Calvó-Armengol, A. and Jackson, M.O. (2004). The effects of social networks on employment and inequality, American Economic Review, Vol. 94, pp. 426-454.

Calvó-Armengol, A. and Zenou, Y. (2005). Job matching, social network and word-of-mouth communication, Journal of Urban Economics, Vol. 57, pp. 500-522.

Card, D. (2001). Immigrant inflows, native outflows, and the local market impacts of higher immigration, Journal of Labor Economics, Vol. 19, pp. 22-64.

Daneshvary, N., Herzog, Jr. H. W., Hofler, R. A., Schlottmann, A. M. (1992). Job search and immigrant assimilation: An earnings frontier approach, Review of Economics and Statistics, Vol. 74, pp. 482-492.

Duncan, B. and Trejo. S. (2010). Selectivity and immigrant employment, Paper presented at the 2010 Population Association of American Annual Meetings. Available for download here: http://paa2010.princeton.edu/download.aspx?submissionId=100596.

Dustmann, C., Glitz, A. and Schönberg, U. (2009). Job search networks and ethnic segregation in the workplace, Paper Presented at 2009 SOLE meetings.

Edin, P. A., Fredriksson, P. and Aslund, O. (2003). Ethnic enclaves and the economic success of immigrants-evidence from a natural experiment, Quarterly Journal of Economics, Vol. 118, pp. 329-357.

Fairlie, R. W. and Meyer, B.D. (1996). Ethnic and racial self-employment differences and possible explanations, Journal of Human Resources, Vol. 31, pp. 757-793.

Farley, R. (1990). The new Census question about ancestry: What did it tells us? Demography, Vol. 28, pp. 411-429.

Furtado, D. and Theodoropoulos, N. (2009). I'll marry you if you get me a job: Cross-nativity marriages and immigrant employment rates, International Journal of Manpower, Vol. 30, pp. 116-126.

Gang, I. N. and Zimmermann, K. (2000). Is child like parent? Educational attainment and ethnic origin, Journal of Human Resources, Vol. 35, pp. 550-569. 
Georgarakos, D. and Tatsiramos, K. (2009). Immigrant self-employment: Does intermarriage matter? Research in Labor Economics, Vol. 29, 253-271.

Goel, D. and Lang, K. (2009). Social ties and the job search of recent immigrants, NBER Working Paper 15186.

Granovetter, M. (1978). Threshold models of collective behavior, American Journal of Sociology, Vol. 83, pp. 1420-1443.

Granovetter, M. (2005). The impact of social structure on economic outcomes, Journal of Economic Perspectives, Vol. 19, pp. 33-50.

Hartog, J., van Praag, M., and van der Sluis, J. (2008). If you are so smart, why aren't you an entrepreneur? Returns to cognitive and social ability: Entrepreneurs versus employees, IZA DP. No. 3648.

Hellerstein, J. K., McInerney, M. and Neumark, D. (2008). Spatial mismatch or racial mismatch, Journal of Urban Economics, Vol. 64, pp. 464-479.

Hellerstein, J. K., McInerney, M. and Neumark, D. (2009). Neighbors and co-workers: The importance of residential labor market networks, NBER Working Paper, No. 14201.

Ioannides, Y. and Datcher Loury, L. (2004). Job information networks, neighbourhood effects and inequality, Journal of Economic Literature, Vol. 47, pp. 1056-1093.

Kalmijn, M., de Graaf, P. M. and Janssen, J. (2005). Intermarriage and the risk of divorce in the Netherlands: The effects of differences in religion and in nationality, Population Studies, Vol. 59, pp. 71-85.

Kantarevic, J. (2004). Interethnic marriages and economic assimilation of immigrants, IZA DP No. 1142.

Lee, L. (2007). Identification and estimation of econometric models with group interactions, contextual factors and fixed effects, Journal of Econometrics, Vol. 140, pp. 333-374.

Meng, X. and Gregory, R.G. (2005). Intermarriage and the economic assimilation of immigrants, Journal of Labor Economics, Vol. 23, pp. 135-175.

Meng, X. and Meurs, D. (2009). Intermarriage, language, and economic assimilation process. A case study of France, International Journal of Manpower, Vol. 30, pp. 127-144.

Munshi, K. (2003). Networks in the modern economy: Mexican immigrants in the U.S. labor market, Quarterly Journal of Economics, Vol. 118, pp. 549-597.

Munshi, K. and Wilson, N. (2008). Identity, parochial institutions, and career decisions: Linking the past to the present in the American Midwest, Unpublished Manuscript. 
Passel, J. S., Capps, R. and Fix. M. E. (2004). Undocumented Immigrants: Facts and Figures. Report Urban Policy Institute, Washington, DC.

Passel, J.S. and Cohn, D. (2009). A Portrait of Unauthorized Immigrants in the United States. Pew Research Center, Washington, DC.

Patacchini, E. and Zenou, Y. (2008). Ethnic networks and employment outcomes, IZA DP. No. 3331.

Patel, K. and Vella, F. (2007). Immigrant networks and their implications for occupational choice and wages, IZA DP. No. 3217.

Qian, Z. and Lichter, D. (2007). Social boundaries and marital assimilation: Interpreting trends in racial and ethnic intermarriage, American Sociological Review, Vol. 72, pp. 68-94.

Ruggles, S., Sobek, M., Alexander, T., Fitch, C. A., Goeken, R., Hall, P. K., King, M. and Ronnander, C. (2004). Integrated Public Use Microdata Series: Version 3.0 [Machine-readable database]. Minneapolis, MN: Minnesota Population Center [producer and distributor].

U.S. Census Bureau, (2000). "Coming to America: A profile of the nation's foreign born" Available online at http://www.census.gov/prod/2000pubs/cenbr002.pdf.

Yuengert, A. (1995). Testing hypotheses of immigrant self-employment, Journal of Human Resources, Vol. 30, pp. 194-204.

Zhang, J. and Song, X. (2007). Fertility differences between married and cohabiting couples: A switching regression analysis, IZA DP No. 3245. 
Table 1. Descriptive Statistics

\begin{tabular}{|c|c|c|c|c|c|c|}
\hline & \multicolumn{2}{|c|}{$\begin{array}{l}\text { Immigrant Male and } \\
\text { Native Spouse }\end{array}$} & \multicolumn{2}{|c|}{$\begin{array}{l}\text { Immigrant Male and } \\
\text { Immigrant Spouse }\end{array}$} & \multicolumn{2}{|c|}{ All } \\
\hline & Mean & $\begin{array}{l}\text { Standard } \\
\text { Deviation }\end{array}$ & Mean & $\begin{array}{l}\text { Standard } \\
\text { Deviation }\end{array}$ & Mean & $\begin{array}{c}\text { Standard } \\
\text { Deviation }\end{array}$ \\
\hline & \multicolumn{6}{|c|}{ Immigrant male characteristics } \\
\hline Employed & 0.869 & 0.337 & 0.764 & 0.425 & 0.797 & 0.403 \\
\hline Age & 39.479 & 10.474 & 35.778 & 8.871 & 36.934 & 9.556 \\
\hline Less than or up to 12 th grade & 0.235 & 0.424 & 0.484 & 0.500 & 0.406 & 0.491 \\
\hline High school graduate, or GED & 0.209 & 0.407 & 0.186 & 0.389 & 0.193 & 0.395 \\
\hline Some college/Associates degree & 0.271 & 0.445 & 0.173 & 0.378 & 0.203 & 0.403 \\
\hline Bachelors/Masters/PhD degree & 0.284 & 0.451 & 0.157 & 0.364 & 0.197 & 0.398 \\
\hline English fluency & 0.823 & 0.381 & 0.470 & 0.499 & 0.580 & 0.494 \\
\hline Veteran & 0.171 & 0.377 & 0.068 & 0.251 & 0.100 & 0.300 \\
\hline Disability & 0.116 & 0.320 & 0.233 & 0.423 & 0.197 & 0.397 \\
\hline White & 0.443 & 0.497 & 0.124 & 0.330 & 0.223 & 0.417 \\
\hline Hispanic & 0.434 & 0.496 & 0.665 & 0.472 & 0.593 & 0.491 \\
\hline Asian & 0.080 & 0.271 & 0.174 & 0.379 & 0.145 & 0.352 \\
\hline Black & 0.040 & 0.196 & 0.034 & 0.181 & 0.036 & 0.186 \\
\hline "Other" Race & 0.003 & 0.057 & 0.003 & 0.055 & 0.003 & 0.056 \\
\hline Years in the U.S. & 30.099 & 12.327 & 22.204 & 9.996 & 24.669 & 11.382 \\
\hline Recent immigrant & 0.016 & 0.127 & 0.032 & 0.176 & 0.027 & 0.162 \\
\hline Percent of MSA with same country of birth & 0.052 & 0.087 & 0.085 & 0.091 & 0.075 & 0.091 \\
\hline Residence in central city & 0.198 & 0.398 & 0.270 & 0.444 & 0.248 & 0.432 \\
\hline Residence outside central city & 0.458 & 0.498 & 0.399 & 0.490 & 0.418 & 0.493 \\
\hline \multirow[t]{2}{*}{ Central city status unknown } & 0.345 & 0.475 & 0.330 & 0.470 & 0.335 & 0.472 \\
\hline & \multicolumn{6}{|c|}{ Spouse characteristics } \\
\hline Spouse employment & 0.645 & 0.479 & 0.463 & 0.499 & 0.520 & 0.500 \\
\hline Spouse's log income & 5.495 & 7.370 & 2.671 & 8.162 & 3.553 & 8.031 \\
\hline Spouse with less than $12^{\text {th }}$ grade & 0.144 & 0.351 & 0.467 & 0.499 & 0.366 & 0.482 \\
\hline Spouse with high school or GED & 0.262 & 0.440 & 0.206 & 0.404 & 0.223 & 0.416 \\
\hline Spouse with some college /Associates degree & 0.327 & 0.469 & 0.182 & 0.386 & 0.228 & 0.419 \\
\hline Spouse with Bachelors/Masters/PhD degree & 0.266 & 0.442 & 0.145 & 0.352 & 0.183 & 0.387 \\
\hline Percent same ancestry & 0.302 & 0.459 & 0.744 & 0.436 & 0.606 & 0.489 \\
\hline Number of observations & \multicolumn{2}{|c|}{23,514} & \multicolumn{2}{|c|}{51,625} & \multicolumn{2}{|c|}{75,139} \\
\hline
\end{tabular}

Notes: The sample consists of married (spouse present), foreign born males between the ages of 18 and 62 who immigrated to the U.S. at or before the age of 18, are not currently enrolled in school, and reside in an identifiable metropolitan statistical area. The English fluency variable takes the value of one if the immigrant speaks only English or speaks English very well. It is equal to zero if the immigrant speaks English well, does not speak English well, or does not speak English at all. The variable, "disability" equals one if the immigrant has a disability which prevents, limits, or causes difficulty in working. The "recent immigrant dummy" equals one if the individual has been in the U.S. for less than 5 years. Statistics are computed using the appropriate person-level weights provided by the 2000 U.S. Census. 
Table 2. Effect of Marriage to a Native on Immigrant Employment

OLS

Variable

Marriage to a native

High school graduate or GED

Some college/Associates degree

Bachelors degree/Masters/PhD

Disability

Veteran

Hispanic

Black

Asian

Other race

Years in the U.S.

Recent immigrant

English fluency

Percent of MSA with same country of birth

Residence in central city

Residence outside central city

Unemployment rate of natives in MSA-age group cells

Age dummies

Region dummies

Country of birth dummies

Adjusted R-squared

Number of observations
(1)

Employment
$0.105 * *$
$(0.003)$

Employment $0.075 * *$

(0.004)

---

$--$

$-$

$--$

$-$

$-$

$--$
(2)

(3)

Employment

$0.049 * *$

(0.004)

$0.066^{* *}$

(0.005)

0.111 **

(0.005)

$0.157 * *$

(0.005)

$-0.062 * *$

(0.005)

$-0.009+$

(0.005)

0.021

(0.015)

$-0.048 * *$

(0.017)

0.012

(0.014)

0.014

(0.026)

$0.002 * *$

(0.0003)

$-0.023^{*}$

(0.011)

$---$

$---$

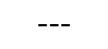

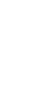

$---$

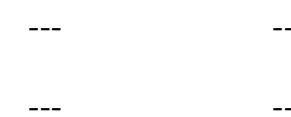

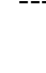

$--$

$--$

Yes

--- Yes

--- Yes

Yes

0.047

75,139
Employment

$0.040 * *$

(0.004)

$0.055 * *$

(0.005)

$0.095 * *$

(0.005)

$0.137 * *$

(0.005)

$-0.061 * *$

(0.005)

$-0.012 *$

(0.005)

0.023

(0.014)

$-0.047 * *$

(0.017)

0.012

(0.014)

0.016

(0.026)

$0.001 *$

(0.0003)

$-0.019+$

(0.011)

$0.055 * *$

(0.004)

$-0.157 * *$

(0.029)

$-0.019 * *$

(0.005)

0.005

(0.004)

---
(4)

(5)

Employment

$0.040 * *$

(0.004)

$0.055 * *$

(0.005)

$0.095 * *$

(0.005)

$0.137 * *$

(0.005)

$-0.061 * *$

(0.005)

-0.012 *

$(0.005)$

0.023

(0.015)

$-0.047 * *$

(0.017)

0.011

$(0.014)$

0.016

(0.026)

$0.001 *$

(0.0003)

$-0.019+$

(0.011)

$0.055 * *$

(0.004)

$-0.143 * *$

(0.030)

$-0.018 * *$

$(0.005)$

0.005

(0.004)

$-0.209$

(0.140)

Yes Yes

Yes Yes

Yes Yes

$0.071 \quad 0.071$

75,139

75,139

the sample and variables. Central city status unknown is the omitted category in specifications which include central city residence variables. Estimates are weighted using the appropriate person-level weights provided by the 2000 U.S. Census. Significance levels are noted by the following: ** significant at 1\%; * significant at 5\%; + significant at $10 \%$. "---" signifies that the variable is not included in the specification. 
Table 3. IV and Placebo Tests Results

\section{SLS}

Other Tests

(1)

Variable

Marriage to a native

High school graduate or GED

Some college/Associates degree

Bachelors degree/Masters/PhD

Disability

Veteran

Hispanic

Black

Asian

Other race

Years in the U.S.

Recent immigrant

English fluency

Percent of MSA with same country of birth

Residence in central city

Residence outside central city

Unemployment rate of natives in MSA-age group cells

Age dummies

Region dummies

Country of birth dummies

IV: Immigrant females over all females in

MSA-age groups cells

IV: Immigrant females over immigrant males in age group-country of birth cells

Marriage to a native

(First Stage)

$$
\text { --- }
$$

$0.034 * *$

$(0.005)$

$0.065^{* *}$

$(0.005)$

$0.071 * *$

(0.006)

$-0.068 * *$

(0.004)

$0.021 * *$

(0.006)

$-0.070 * *$

(0.016)

$-0.111 * *$

(0.022)

$-0.271 * *$

(0.019)

$-0.130 * *$

(0.034)

$0.016 * *$

$(0.0004)$

$-0.082 * *$

(0.010)

$0.132 * *$

(0.004)

$0.275^{* *}$

(0.041)

$-0.014 * *$

$(0.005)$

$0.010 * *$

(0.004)

$0.273+$

(0.140)

Yes

Yes

Yes

$-0.495 * *$

(0.018)

$-0.062 * *$

(0.018)

Adjusted R-squared

Hansen J-statistic

P-value of Hansen J-statistic

F statistic for weak identification

Number of observations

$---$

$---$

---

394.19

75,139
Employment

(Second Stage)

$0.059 *$

(0.030)

$0.054 * *$

(0.005)

(0.006)

$0.135 * *$

(0.006)

$-0.059 * *$

(0.005)

$-0.013 *$

(0.005)

$0.025+$

(0.015)

$-0.045^{* *}$

(0.017)

(0.016)

(0.028)

(0.001)

$-0.017$

$(0.011)$

$0.052 * *$

(0.006)

$-0.144 * *$

(0.033)

$-0.018 * *$

(0.005)

(0.004)

$-0.251+$

(0.132)
(2)

(3)

(4)

$0.094 * *$

0.017

0.018

0.001

0.005

Yes

Yes

Yes

Yes

---

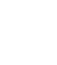

$---$

---

---

0.286

0.594

(3)

Years of schooling

Self-care disability

-

$---$

$--$

$-0.447 * *$

(0.033)

$0.301 * *$

(0.039)

$-0.309 * *$

(0.120)

0.008

(0.124)

$0.750 * *$

(0.106)

$-0.084$

(0.206)

$0.089 * *$

(0.003)

$0.323 * *$

(0.088)

$2.050 * *$

(0.033)

$-1.236^{* *}$

(0.353)

$-0.014$

(0.036)

$0.179 * *$

(0.031)

$-1.435$

(1.103)

Yes

Yes

Yes

$0.593 * *$

(0.135)

$0.293 * *$

(0.114)

0.453

---

75,139

\section{--- \\ $-0.006 * *$ \\ (0.001) \\ $-0.010 * *$ \\ (0.001) \\ $-0.013 * *$ \\ (0.001)}

---

0.001

(0.001)

0.001

(0.003)

$0.013 *$

(0.006)

0.002

(0.004)

$-0.004$

(0.004)

$-0.0001+$

(0.00008)

$-0.0003$

(0.003)

$-0.002+$

(0.001)

$-0.006$

(0.008)

0.001

(0.001)

$-0.0009$

(0.0009)

0.041

(0.034)

Yes

Yes

Yes

$-0.0004$

(0.004)

0.003

(0.005)

0.004

---

---

75,139
---

$--$

75,139

Notes: See Taple 1 notes for information on the sample and variables. Central city status unknown is the omitted category in specifications which include central city residence variables. Estimates are weighted using the appropriate person-level weights provided by the 2000 U.S. Census. In all specifications, standard errors are clustered on age-country of birth-MSA cells. Significance levels are noted by the following: ** significant at 1\%; * significant at 5\%; + significant at 10\%. "---" signifies that the variable is not included in the specification or that the relevant statistic is not available. 
Table 4. Gains to Legal Status

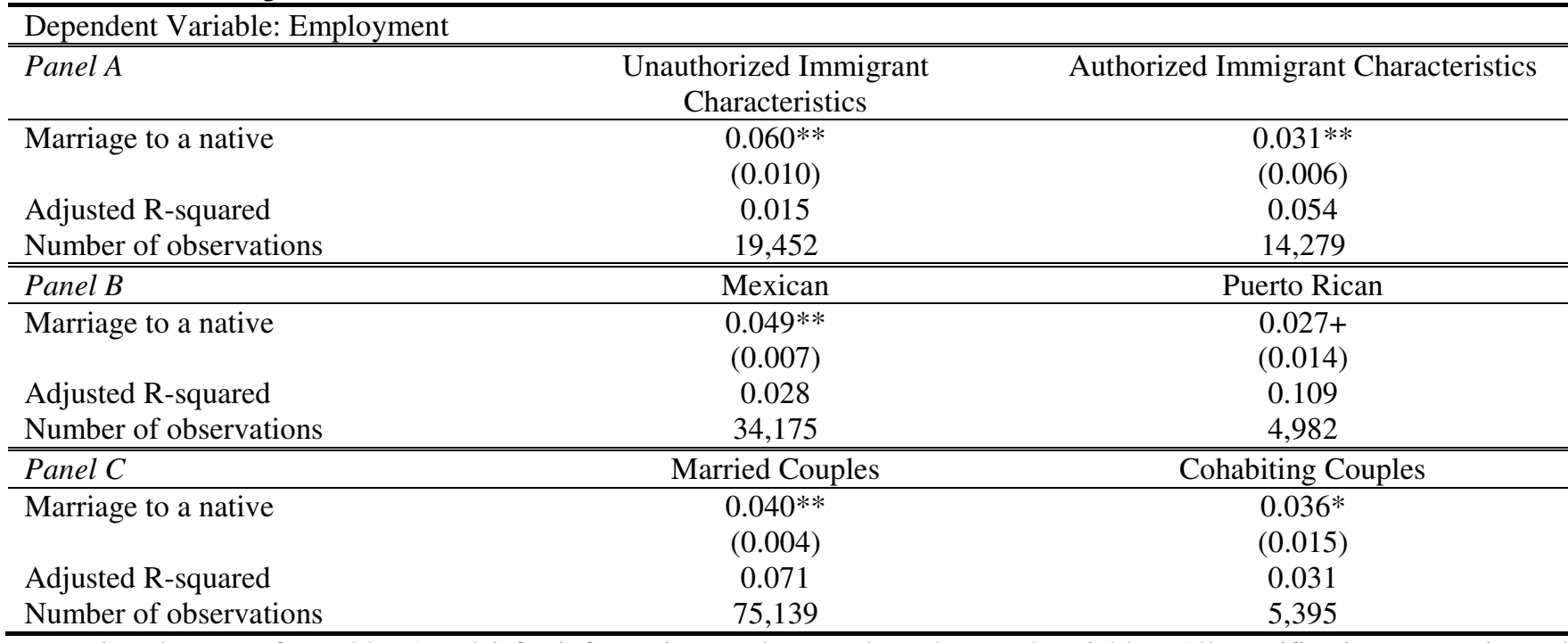

Notes: See the notes for Tables 1 and 2 for information on the sample and control variables. All specifications are estimated using OLS and include the full list of control variables, as shown in column 3 of Table 2. In panel A, the regressions are run separately on immigrants with observable characteristics that are common among the undocumented immigrant population in the U.S. The "unauthorized immigrant characteristics" are that they come from Mexico or Central America, reside in California, Texas, Florida or New York, and have less than a high school degree. Immigrants with "authorized immigrant characteristics" have none of these characteristics. Panel B compares Mexicans and Puerto Ricans in terms of the returns to marrying a native. Panel $\mathrm{C}$ considers the returns to sharing a household with an opposite sex native for married and cohabiting immigrants. Estimates are weighted using the appropriate person-level weights provided by the 2000 U.S. Census. Significance levels are noted by the following: ** significant at $1 \%$; * significant at $5 \%$; + significant at $10 \%$. 
Table 5. Spouse Characteristics and the Effect of Marriage to a Native on Immigrant Employment

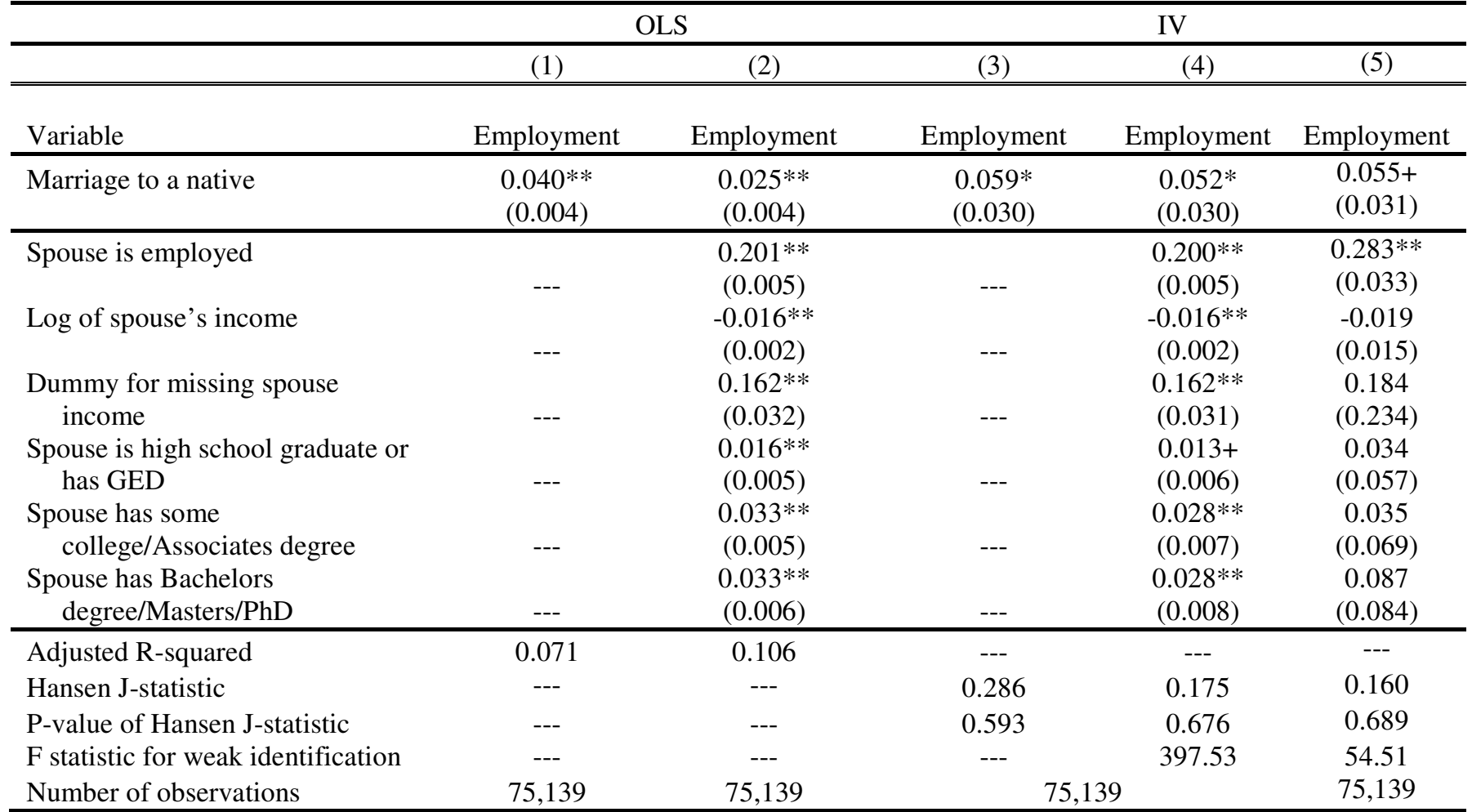

Notes: See the notes for Tables 1 and 2 for information on the sample and control variables. All specifications include the full list of control variables, as shown in column 3 of Table 2. Spouse's income includes pre-tax wage and salary income for the previous year. First stage regression results associated with columns 3, 4 and 5 are similar to those shown in column 4 of Table 2 and are available upon request. In the 2SLS specifications, standard errors are clustered on age-country of birth-MSA cells. Estimates are weighted using the appropriate person-level weights provided by the 2000 U.S. Census. Significance levels are noted by the following: ** significant at $1 \%$; * significant at $5 \%$; + significant at $10 \%$. "--." signifies that the variable is not included in the specification, or that the relevant statistic is not available. 
Table 6. Tests of Network Hypotheses

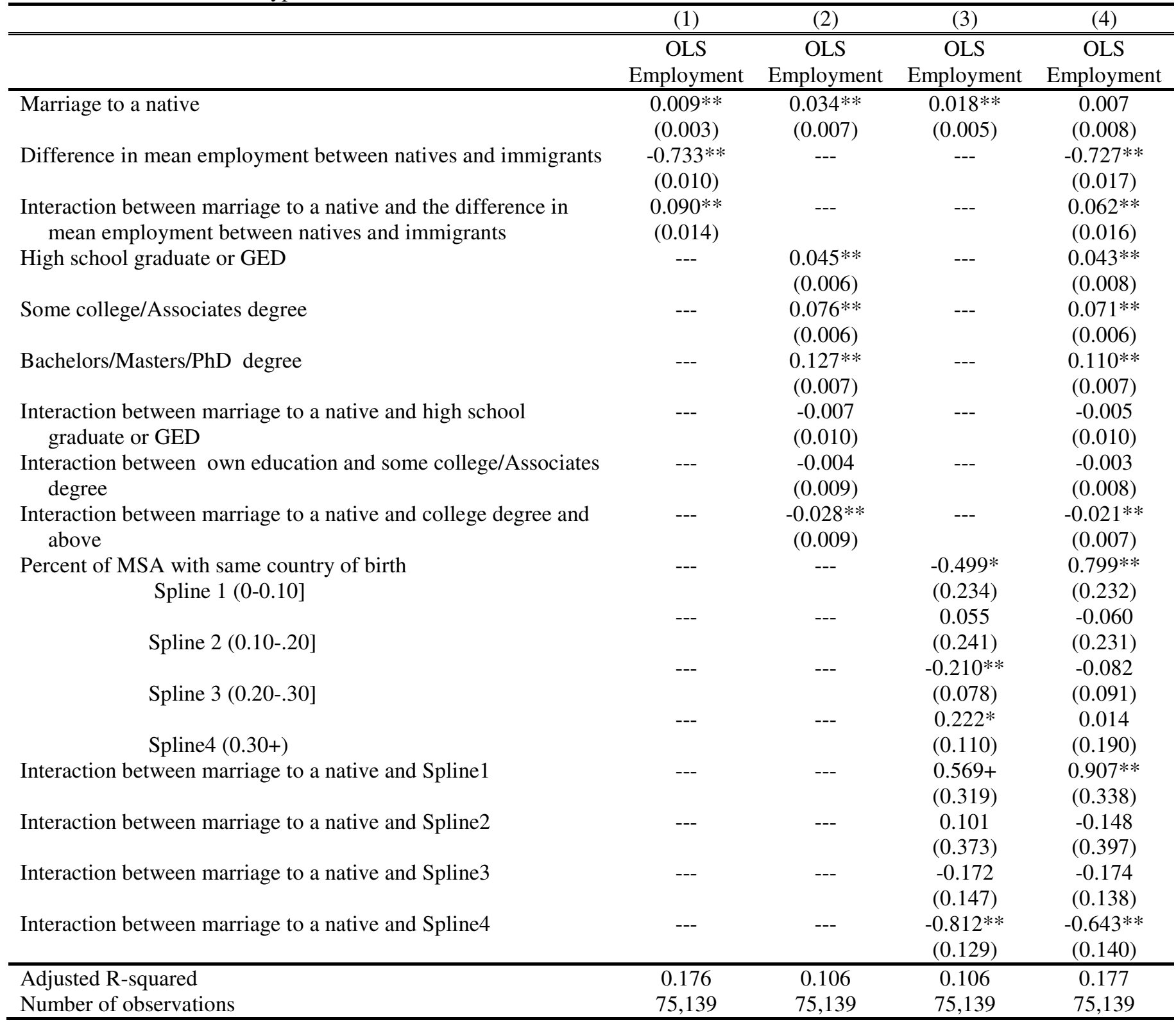

Notes: See the notes for Tables 1 and 2 for information on the sample and variables. All specifications are estimated using OLS and include the full list of control variables, as shown in column 3 of Table 2 as well as the spouse characteristics in Table 4 . In specifications where the variable of interest varies by MSA, age group and country of birth (columns 1, 2 and 3), standard errors are clustered on MSA-country of birth-age cells (26078). In column 4, standard errors are clustered on MSA cells (283). **significant at $1 \%$; * significant at $5 \%$; + significant at $10 \%$. ${ }^{---. " ~ s i g n i f i e s ~ t h a t ~ t h e ~ v a r i a b l e ~ i s ~ n o t ~ i n c l u d e d ~ i n ~ t h e ~ s p e c i f i c a t i o n ~}$ except for the three educational qualification dummies. 
Table 7. Additional Network Hypotheses

\begin{tabular}{lcccc}
\hline & 1 & 2 & 3 & 4 \\
\hline & OLS & & Multinomial Logit & Not employed \\
& $\begin{array}{c}\text { Percent immigrant in } \\
\text { occupation within MSA }\end{array}$ & Paid employment & Self employment & \\
\hline Marriage to a native & $-0.035^{* *}$ & $0.027^{* *}$ & 0.003 & $-0.030^{* *}$ \\
& $(0.002)$ & $(0.004)$ & $(0.003)$ & $(0.004)$ \\
\hline $\begin{array}{l}\text { Adjusted R-squared } \\
\text { Number of }\end{array}$ & 0.397 & --- & --- & 75,139 \\
observations & 59,906 & 75,139 & & 75,139 \\
\hline
\end{tabular}

Notes: See the notes for Table 1 and 2 and for information on the sample and variables. All specifications include the full list of control variables, as shown in column 3 of Table 2 as well as the spouse characteristics in Table 4 . In columns 1 and 5 , the sample is restricted to employed workers. Columns 2, 3 and 4 present marginal effects evaluated at variable means from a multin $\phi$ mial logit model. ** significant at $1 \%$; * significant at $5 \%$; + significant at $10 \%$. "---" signifies that the relevant statistic is not available. 